\title{
ライトフィールドからの煙の空間濃度分布推定
}

\section{Estimation of Smoke Spatial Density from Light Field}

\author{
井手口 裕太 $^{\dagger 1}$, \\ 黒田嘉宏 ${ }^{\dagger}$, \\ 浦 西 友 樹†2, \\ 井 村 誠 孝 $^{\dagger}$, \\ 吉 元 俊 輔 ${ }^{\dagger}$, \\ 大城 理 ${ }^{\dagger 1}$
}

Yuta Ideguchi $^{\dagger 1}$, Yuki Uranishi ${ }^{\dagger 2}$, Shunsuke Yoshimoto ${ }^{\dagger 1}$, Yoshihiro Kuroda $^{\dagger 3}$, Masataka Imura ${ }^{\dagger 4}$ and Osamu Oshiro ${ }^{\dagger 1}$

あらまし 煙の空間濃度分布の計測は流れの可視化など様々な分野への応用が期待されるが, 煙の動的な空間濃度分布を推定する 手法はいまだ確立されていない. 本研究では, 煙の空間濃度分布の推定のために，ライトフィールドカメラを用いた方法を提案する. 提案手法では，煙をライトフィールドカメラにより撮影し，得られたライトフィールドから初期濃度分布を決定する. 初期濃度分布 はカメラの視線方向に対するボケの影響を含んでいるため，煙の光学的モデルに基づいた最適化により，空間的ボケを除去すること で，煙の空間濃度分布を推定する，本論文ではシミュレーション実験および実測による実験を行い，提案手法の評価を行った。シミュ レーションにより濃度分布を推定できることが定量的に示され，ボケ除去の手法の有効性が示唆された。また，実測により，煙の濃 度分布推定が可能であることが確認できた。

\section{キーワード：ライトフィールド，煙，空間濃度分布推定}

\section{1. ま え がき}

煙の空間濃度分布の計測は, 効率的な換気ダクトの設計, 火災時の煙の充満状況の可視化, 大気中の霧や粉塵の飛翔 状況の把握などに有用である。また，計測した煙の濃度分 布を利用して煙のアニメーションなど映像コンテンツの作 成にも応用が期待されている。実計測に基づくコンピュー タグラフィックスでは, 実際の物体の 3 次元形状やテクス チャの計測が行われてきた ${ }^{12)}$ 。計測対象として，かつては 不透明物体が主体的であったが，近年では不透明物体だけ ではなく, 半透明物体を対象とした研究もある ${ }^{3)}$. しかしこ の計測手法は，物体内部が均一で明確な界面を有する対象 の表面形状の 3 次元形状を取得することを目的としている. 本研究で対象とする煙は, 半透明であることに加え, 明確 な界面を有しないため，空間濃度分布の計測が難しいこと が知られている。

煙の空間濃度分布を計測する手法として，レーザ光を走 査してカメラで撮影することで煙の空間濃度分布を取得す る手法4)5) があるが，複数回の撮影が必要となり，動的な

\footnotetext{
2015 年 7 月 21 日受付，2016年 4 月 28 日再受付，2016年6月 17 日採録 $\dagger 1$ 大阪大学 大学院基礎工学研究科

（干 560-8531 大阪府豊中市待兼山町 1-3，TEL 06-6850-6501） $\dagger 2$ 京都大学 医学部附属病院

（₹ 606-8507 京都府京都市左京区聖護院川原町 54，TEL 075-751-3646 $\dagger 3$ 大阪大学 サイバーメディアセンター

（干 560-0043 大阪府豊中市待兼山町 1-32，TEL 06-6850-6063） $\uparrow 4$ 関西学院大学 理工学部

( ⿳ 669-1337 兵庫県三田市学園 2-1, TEL 079-565-7437)
}

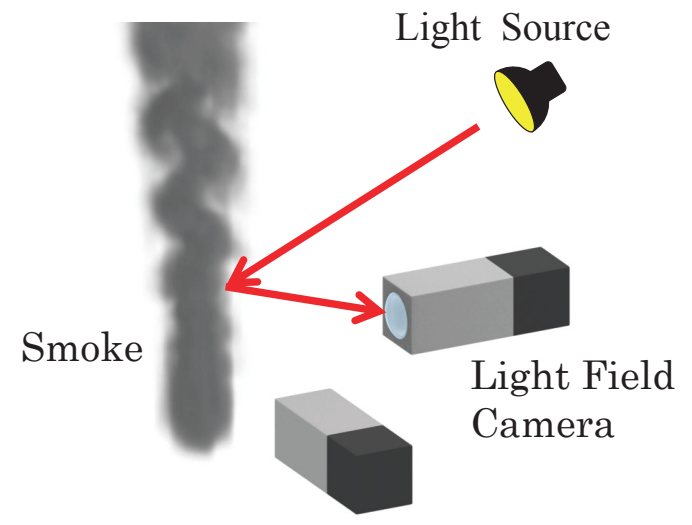

図 1 提案手法

様子を捉えることは難しい. 煙の空間濃度分布を光学的に 計測するには，煙の粒子が存在する空間のすべての位置の 散乱光強度を求める必要がある。 そのためには, 従来手法 のように光を散乱させる位置を時間的に変更しつつ散乱光 を取得するか，煙全体での散乱光を周囲の様々な位置や方 向から取得する必要がある。通常のカメラに比べて多くの 光学的情報を取得可能なカメラとして, ライトフィールド カメラ ${ }^{6)-8)}$ がある. ライトフィールドカメラは, レンズに 到達した光の強度 ·位置 ·方向の情報 (ライトフィールド) を一度の撮影で記録でき，煙の動態を調べるのに良好な時 間サンプリングが得られる。近年，ライトフィールドから 透明物体を識別する手法 ${ }^{9)}$ や, 空気と屈折率の異なる透明 なガスの空間濃度分布をライトフィールドから計測する手 
法 ${ }^{10)}$ など，ライトフィールドを用いて屈折を生じる透明物 体の形状や濃度分布を計測する手法が提案されている。こ れらの研究では透明な物質を対象としているが，周囲の光 情報から内部の光の情報を得ており, 煙の空間濃度分布推 定においてもライトフィールドの解析が有用な手段である と考えられる。しかしながら, 煙の濃度分布計測にライト フィールドカメラを用いた研究は行われていなかった。

本研究ではライトフィールドカメラを用いることで，一 度の撮影で煙の空間濃度分布を推定する方法を提案する. 図 1 に示すように，複数のライトフィールドカメラにより 煙を撮影し，取得したすべてのライトフィールドと同等の ライトフィールドを発生させる煙の空間濃度分布を推定す る. 本論文では，シミュレーションデータを用いて提案手 法を評価し，さらに煙の濃度分布の実測結果を示す。

\section{2. 関 連 研 究}

物体表面の 3 次元形状を計測する様々な研究が古くより 行われてきているが，金属や鏡など完全拡散反射表面を有 しない物体の表面形状や，煙など界面自体が明確でない物 体の形状や濃度分布を計測することは, コンピュータビジョ ンにおいて現在でも困難な課題のひとつである。本節では, これらの計測に関連する研究をまとめるとともに，本論文 で提案する煙の濃度分布計測手法の意義を明らかにする。

完全拡散反射表面を有しない物体の形状を計測するため の手法として，反射光の偏光から鏡面反射表面を有する物 体の 3 次元形状を計測する手法 ${ }^{11)}$ や, 偏光を利用して屈折 率が既知の透明物体の 3 次元形状を計測する手法 ${ }^{12) 13)}$, 透 明な物体にスリット光を投影し，物体の形状を計測する手 法 ${ }^{14)}$ などが提案されている。これらの手法は，明確な界面 を有する物体の形状は計測できるものの，界面が明確では ない対象を計測することは対象としていない。一方，羽毛 や木の葉など，境界が明確とならない物体の境界付近にお ける見え方を表現するための手法として，計測空間をボク セルに分割し，複数視点のカメラからボクセルごとの不透 明度を決定する手法 ${ }^{1)}$ が提案されている. しかしながらこ の手法は，物体表面付近の不透明度分布の推定を目的とし ており，対象物内部の空間分布の計測には至っていない.

煙の内部の空間濃度分布を計測する方法として，レーザ 光を走査しながらカメラで複数回撮影した画像を用いる方 法がある(4)5)。しかしながら，この手法はレーザ光を走査し ながら複数回の撮影を必要とする。したがって，時間的変 動の大きな煙においては煙の全体を撮影している間に煙が 変化するため，時間的にズレのある空間濃度分布を計測す ることになる。

近年，複雑な光学的特性を有する物体の表面形状や内部 分布を計測する手法として，ライトフィールドを用いた手 法が注目されている。ライトフィールドは，光の強度だけ でなく位置や角度など多くの情報も含んでいるため，計測 対象の周囲のライトフィールドを解析することで内部の光
の情報を取得できると考えられる。ライトフィールドを用 いた手法として，透明物体を通過する光線の屈折から透明 物体を識別する手法9)や，コード化された光源と複数のカ メラを用いて光線の屈折から透明なガスの空間濃度分布を 計測する手法 ${ }^{10)}$ が提案されている。このライトフィールド は，ライトフィールドカメラ6) 8) によって一度の撮影で取 得することができる。従来手法では複数回の撮影を必要と するため，変動の大きな煙において時間的ズレが発生する が，煙の空間濃度分布計測にライトフィールドカメラを用 いることで，この問題を解決することができる.

煙をライトフィールドカメラで撮影した場合，各位置で の光の散乱強度の情報を含んだライトフィールドを取得す ることができる，煙の濃度と光の散乱強度相関があるため， これらの情報より煙の空間濃度分布を推定することが可能 である。本論文では，ライトフィールドカメラを用いるこ とで一度の撮影で，煙の空間濃度分布を推定する手法を提 案する．光源からの光が煙に入射することで散乱が生じる. 散乱が生じている空間のライトフィールドを取得し，取得 したすべてのライトフィールドと同等のライトフィールド を発生させる煙の空間濃度分布を最急降下法を用いて推定 する。

\section{3. 煙の光学的モデル}

本研究では，煙の光学的モデルに基づき，計測したライ トフィールドと同等なライトフィールドを生じる煙の空間 濃度分布を推定する。本節では，煙をライトフィールドカ メラで撮影した際に，ライトフィールドカメラに到達する 光の強度と煙の濃度との関係性について説明する。本研究 では，Hawkins や Fuchs らの研究4)5) と同様に，背景が視 認できるほど低い濃度の煙を対象とする。

図 2 に示すように，光源からの光は煙で散乱し，煙を通 過してライトフィールドカメラに到達する。ここで光線の 方向のみ考え，散乱した光がライトフィールドカメラに到 達する方向を $\omega$ とし, $\omega$ 上の点の位置を $p_{\omega}, p_{\omega}^{\prime}$ とし, ライ トフィールドカメラの位置を $p_{\text {cap }}$, 位置 $p_{\omega}$ での煙の濃度を $D\left(p_{\omega}\right)$, 煙の吸光断面係数を $\sigma$, 位置 $p_{\omega 1}$ から位置 $p_{\omega 2}$ の 透過率を $\tau\left(p_{\omega 1}, p_{\omega 2}\right)$, 位置 $p_{\omega}$ でのライトフィールドカメ ラ方向の散乱光を $I_{d}\left(p_{\omega}\right)$, 位置 $p_{\mathrm{bg}}$ にある背景の光の強度 を $I_{\mathrm{bg}}$ と表現するとき，煙を通過してライトフィールドカ メラに到達する光の強度 $I_{\text {cap }}$ は以下のように表される ${ }^{15)}$.

$$
\begin{aligned}
I_{\text {cap }}= & \int_{p_{\mathrm{bg}}}^{p_{\text {cap }}} \sigma D\left(p_{\omega}\right) \tau\left(p_{\omega}, p_{\text {cap }}\right) I_{d}\left(p_{\omega}\right) d p_{\omega} \\
& +I_{\mathrm{bg}} \tau\left(p_{\mathrm{bg}}, p_{\text {cap }}\right) \\
\tau\left(p_{\omega}, p_{\text {cap }}\right)= & \exp \left(-\int_{p_{\omega}}^{p_{\text {cap }}} \sigma D\left(p_{\omega}^{\prime}\right) d p_{\omega}^{\prime}\right)
\end{aligned}
$$

背景が充分に暗い場合には，式 (1) の第二項は無視できる ため以下の様になる。 


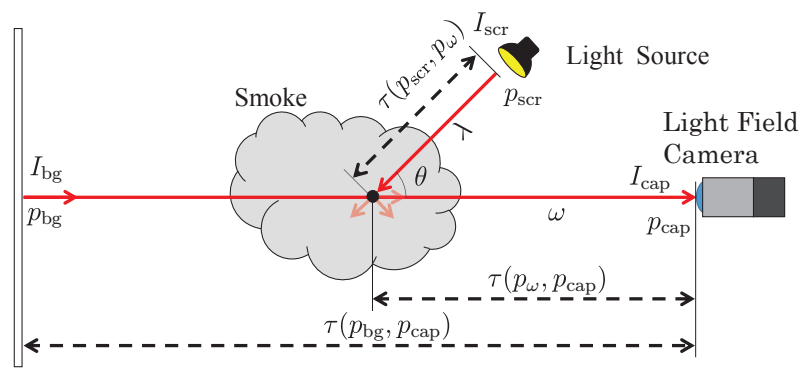

図 2 煙を通過する光

$$
I_{\text {cap }}=\int_{p_{\mathrm{bg}}}^{p_{\text {cap }}} \sigma D\left(p_{\omega}\right) \tau\left(p_{\omega}, p_{\text {cap }}\right) I_{d}\left(p_{\omega}\right) d p_{\omega}
$$

煙の濃度が低い場合，多重散乱を無視した散乱光の表現が 可能である ${ }^{4) 5)}$. 光源の光の強度を $I_{\mathrm{src}}$, 光源の光軸の方向 を $\lambda, \lambda$ 上の点の位置を $p_{\lambda}$, 光源の位置を $p_{\mathrm{src}}, \omega$ と $\lambda$ のな す角を $\theta$, フェーズ関数を $P(\theta)$ とするとき, 散乱光 $I_{d}\left(p_{\omega}\right)$ は以下の式で表現される。

$$
\begin{aligned}
I_{d}\left(p_{\omega}\right) & =I_{\mathrm{src}} \tau\left(p_{\mathrm{src}}, p_{\omega}\right) P(\theta) \\
\tau\left(p_{\mathrm{src}}, p_{\omega}\right) & =\exp \left(-\int_{p_{\mathrm{src}}}^{p_{\omega}} \sigma D\left(p_{\lambda}\right) d p_{\lambda}\right)
\end{aligned}
$$

入射光の方向による散乱を表すフェーズ関数 $P(\theta)$ は，レ イリー散乱では $1+\cos \theta$ となる。また, 煙の濃度が低い場

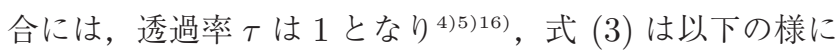
なる。

$$
I_{\text {cap }}=\int_{p_{\mathrm{bg}}}^{p_{\text {cap }}} \sigma D\left(p_{\omega}\right) I_{\mathrm{src}} P(\theta) d p_{\omega}
$$

光源をライトフィールドカメラと煙から充分遠くに配置す ることで, 光源を平行光源であると見なすことができる. また, 煙の存在範囲の大きさに対し, 煙からライトフィール ドカメラまでの距離が充分大きくなるようにライトフィー ルドカメラを配置することで, $\theta$ は一台のライトフィール ドカメラに対して煙内のどの点においても等しくなるため, $P(\theta)$ も一定となる.さらに, 各ライトフィールドカメラ の $P(\theta)$ を同じにするため, $\theta$ が同じになる位置にライト フィールドカメラを配置する．また， $\sigma$ は煙の粒子径によっ て決定される係数であり, $I_{\mathrm{src}}$ は定数であるため, 式 (1) は 最終的に以下の様になる。

$$
I_{\text {cap }} \propto \int_{p_{\text {cap }}}^{p_{\mathrm{bg}}} D\left(p_{\omega}\right) d p_{\omega}
$$

\section{4. 煙の空間濃度分布推定手法}

本節では，計測されたライトフィールドと前述の煙の光 学的モデルに基づいたライトフィールドが同等になるよう な煙の空間濃度分布を推定する手法について説明する。

提案手法では, 3 次元空間を離散化し, 各位置における濃 度を推定する。図 1 に示すように，まず，ライトフィール ドカメラにより煙が存在する空間を撮影する。ただし一台 のライトフィールドカメラでも計測は可能であるが，解の
不定性を緩和するため複数台での撮影を考える．次に，各 ライトフィールドカメラにより得られた光線情報を 3 次元 空間に逆投影し，各位置における輝度值（逆投影輝度）を 求める．各ライトフィールドカメラによる逆投影輝度が最 小となる值を初期濃度に決定する. 煙の光学的モデルとし て説明したとおり，取得したライトフィールドは光線方向 の濃度の積分值であるため, 逆投影輝度はカメラの視線方 向に対してボケが生じる。本研究ではこれを, 空間的ボケ と呼ぶ.これにより，初期濃度分布は空間的ボケの影響を 受けた濃度分布となる。したがって，正しい煙の空間濃度 分布を推定するためには，この空間的ボケを除去する必要 がある。提案手法では，この空間的ボケをモデル化し，繰 り返し計算による最適化に基づいてモデルのパラメータを 推定し，空間的ボケを除去することで煙の空間濃度分布を 推定する.

\section{1 光線情報の 3 次元空間への逆投影}

ライトフィールドカメラは, 任意の距離にピントを合わせ た画像 (リフォーカス画像) を再構成できる。このリフォー カス画像は, ライトフィールドカメラで取得した光線情報を 3 次元空間に逆投影した際の焦点面での逆投影輝度を表し たものである。以下にリフォーカス画像の再構成法を記す。

ライトフィールドカメラは, メインレンズと撮像素子の 間にマイクロレンズアレイが配置されている8). マイクロ レンズアレイと撮像素子により得られる像は, 仮想的なピ ンホールカメラアレイにより撮影した像と考えることが可 能である.ここで, 横方向に $u_{n}$ 個, 縦方向に $v_{n}$ 個のピン ホールカメラが距離 $d_{\mathrm{phc}}$ の間隔で配置されているカメラア レイを考える。図 3 (a) に示すように, カメラ $(0,0)$ のカメ ラアレイの中心からの座標を $\left(u_{\text {off }}, v_{\text {off }}\right)$ とし, カメラ $(u, v)$ により得られる画像を $I_{\mathrm{phc}}^{(u, v)}(X, Y)$ とするとき, リフォー カス画像 $I_{\mathrm{ref}}(X, Y, \alpha, F)$ は以下のように求められる8). こ のとき $F$ はレンズと撮像面との距離, $\alpha$ はリフォーカス画 像の撮像面とレンズの距離を $F^{\prime}$ とした時の $F$ に対する比 $F^{\prime} / F$ である.

$$
\begin{aligned}
I_{\mathrm{ref}}(X, Y, \alpha, F) & =\frac{1}{\alpha^{2} F^{2}} \sum_{u} \sum_{v} I_{\mathrm{phc}}^{(u, v)}\left(X^{\prime}, Y^{\prime}\right) \\
X^{\prime} & =\left(u d_{\mathrm{phc}}+u_{\mathrm{off}}\right)\left(1-\frac{1}{\alpha}\right)+\frac{X}{\alpha} \\
Y^{\prime} & =\left(v d_{\mathrm{phc}}+v_{\mathrm{off}}\right)\left(1-\frac{1}{\alpha}\right)+\frac{Y}{\alpha}
\end{aligned}
$$

したがって, $I_{\mathrm{phc}}^{(u, v)}(X, Y)$ を $\alpha$ 倍に拡大し, $\left(\left(u d_{\mathrm{phc}}+\right.\right.$ $\left.\left.u_{\text {off }}\right)(1-1 / \alpha),\left(v d_{\text {phc }}+v_{\text {off }}\right)(1-1 / \alpha)\right)$ だけ平行移動さ せて足し合わせることで, リフォーカス画像を再構成する ことができる。

以下に，図 4 (a) に示すような三つのバーチャルカメラ によるカメラアレイで対象物体を撮影した場合を例に，リ フォーカスについて説明する．対象物 A および B を三つの バーチャルカメラによって撮影する事を考えるとき, それぞ 


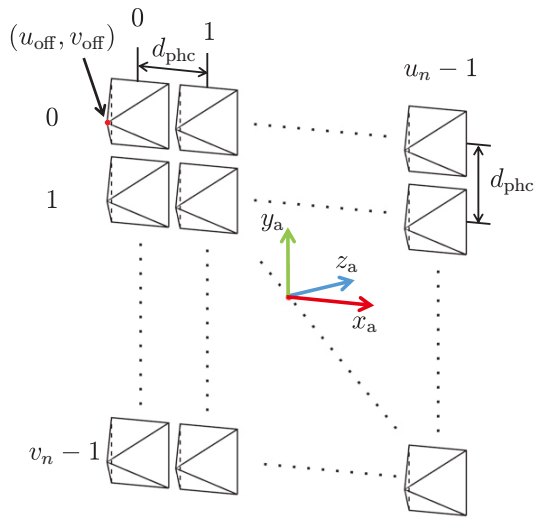

(a) カメラアレイ
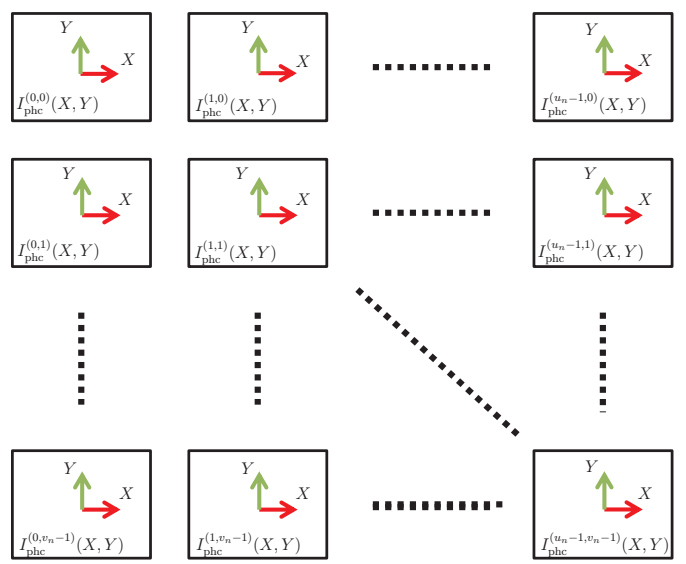

(b) カメラアレイの取得画像

図 3 カメラアレイ画像

れのカメラから取得できる画像は図 4 (b), (c) および (d) に示すようになる。図 5 は, 式 $(8)$ をもとにリフォーカス 画像を再構成した際の, 平行移動量の違いによるリフォー カス画像の違いを示している。(a)に示すように移動距離 が0のときは無限遠にピントが合った画像となる。同様に, 移動距離が大きくなるに連れて対象物 B にピントが合った 画像 (b), 対象物 A にピントが合った画像 (c) というよう に，ピント面の距離がカメラに近付いていくリフォーカス 画像を再構成できることがわかる。なお，ここでは撮像面 の横方向の足し合わせについて述べているが，撮像面の縦 方向の足し合わせについても同様に行える.

図 6 に示すような, 内部パラメータおよび姿勢が同一で, カメラ L およびカメラ R のつのピンホールカメラで, カ メラ L の光軸上に存在する点 $p$ を撮影することを考える. この条件では, カメラ $\mathrm{R}$ の撮像面上における点 $p$ の写る位 置と光軸の距離 $x_{p}$ と, 点 $p$ と点 $p$ の写る位置を結ぶ線と 光軸がなす角 $\theta_{p}$ の関係は以下の様になる.

$$
\theta_{p}=\frac{x_{p}}{f_{\mathrm{phc}}}=\frac{d_{\mathrm{phc}}}{L_{p}}
$$

ここで, $f_{\mathrm{phc}}$ は焦点距離, $d_{\mathrm{phc}}$ はカメラ間距離, $L_{p}$ はカメ ラ L から点 $p$ までの距離を表している。ささらに, カメラか ら取得する画像の水平方向のピクセル数を $W_{\mathrm{phc}}$ とし, $x_{p}$ の点での中心からのピクセル数を $X_{p}$ とし, カメラの画角

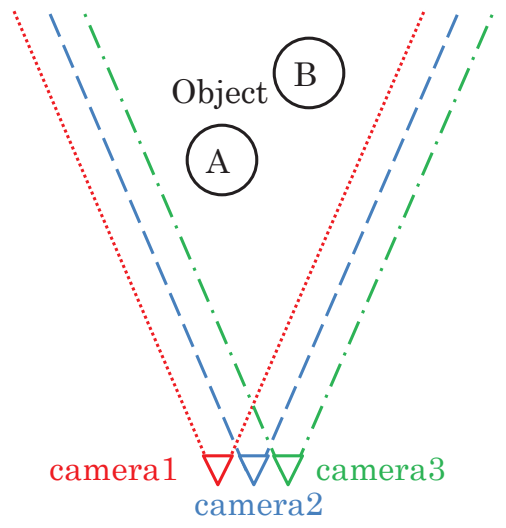

(a) カメラアレイによる物体の撮影

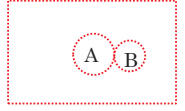

(b) camera1

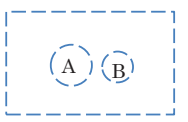

(c) camera 2

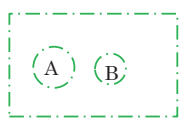

(d) camera3
図 4 カメラアレイにより得られる画像

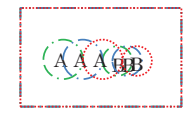

(a) infinity

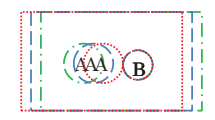

(b) Object B

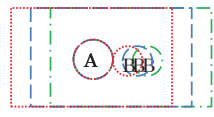

(c) Object A
図 5 アレイ画像によるリフォーカス

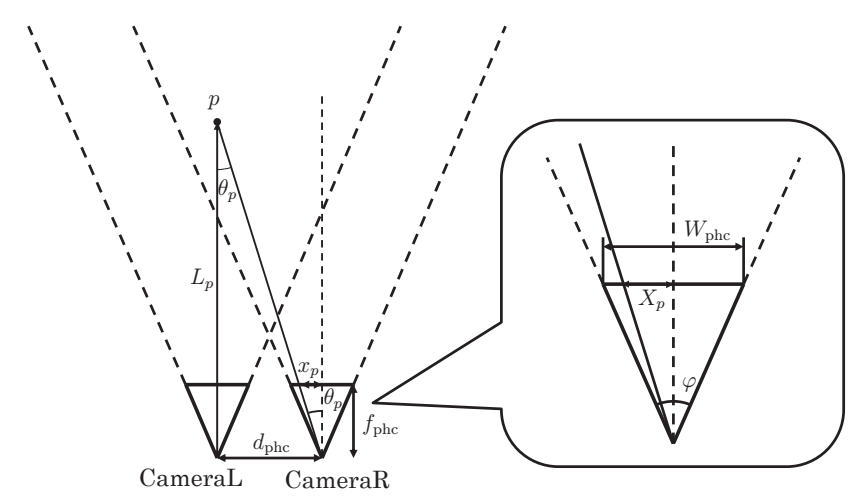

図 6 カメラと空間中の点の位置関係

を $\varphi$ とすると，それぞれの関係は以下のようになる。

$$
\begin{aligned}
\frac{X_{p}}{\frac{W_{\mathrm{phc}}}{2}} & =\frac{x_{p}}{f_{\mathrm{phc}} \tan \frac{\varphi}{2}} \\
X_{p} & =\frac{W_{\mathrm{phc}} d_{\mathrm{phc}}}{2 L_{p} \tan \frac{\varphi}{2}}
\end{aligned}
$$

つまり, カメラの画角が $\varphi$ のとき, カメラから距離 $L_{p}$ に 存在する点は, カメラ $\mathrm{R}$ では中心から $X_{p}$ ピクセル右に映 ることになる，従って，カメラ $\mathrm{R}$ の画像を，右に $X_{p}$ ピク セル平行移動させて足し合わせることで，焦点面が距離 $L_{p}$ の画像を再構成できることがわかる。

\section{2 初期濃度分布の決定}

まず，各ライトフィールドカメラにより得られた光線情 報を 3 次元空間に逆投影する。リフォーカス画像は，逆投 影した際の焦点面での逆投影輝度を表したものであるため, 逆投影にリフォーカス画像の輝度值を利用する。この輝度 
值と濃度は式（7）に示すように，積分したものに比例する ので，この輝度值を濃度として扱う。各ライトフィールド カメラにより得られた逆投影輝度は, 空間的ボケの影響を 含んでいるため, 得られた濃度分布は正しい濃度分布に空 間的ボケが重畳された值となる。したがって，位置によっ ては真の濃度が 0 であっても得られた濃度が 0 でなくなる 問題が発生する。この問題を緩和するため，以下のように 各ライトフィールドカメラによる逆投影輝度の最小值を初 期濃度分布とすることでより正しい濃度分布が得られる。

$$
D_{\text {init }}(\boldsymbol{x})=\min _{j}\left\{D_{\text {pro }, j}(\boldsymbol{x})\right\}
$$

ここで $D_{\mathrm{pro}, j}(\boldsymbol{x})$ は, ライトフィールドカメラ $j$ により得 られた光線情報を位置 $\boldsymbol{x}=(x, y, z)$ に逆投影した際の逆投 影輝度である。ただし, 煙よりも推定範囲を大きく取り，推 定範囲内に濃度が 0 の領域が広い場合を想定しており，必 ずしも最小值の割り当てが効果的であるとは限らない.

\section{3 空間的ボケの除去}

より正しい煙の空間濃度分布を推定するため，空間的ボ ケの影響を除去する必要がある。そのためにまず，空間的 ボケをモデル化する。次に，繰り返し計算により空間的ボ ケを除去することで，煙の正しい空間濃度分布を推定する。

（1） 空間的ボケのモデル化

図 7 に示すように，点 $p$ から発せられる光は，レンズの 開口を通り, 撮像面内のボケ幅 $b^{\prime}$ 内に到達する。ボケ幅 $b^{\prime}$ 内の光線の光量の総和はボケ幅 $b^{\prime}$ によらず一定であり，か つ $b^{\prime}$ の範囲内に一様に分布する。このとき，空間的ボケの 形状は開口の形状に依存すると考えられる。本論文では, 一辺の長さが $d_{\text {len }}$ の正方形の開口であると仮定し, 空間的 ボケを表現する. 点 $q$ に投影された逆投影輝度は, 点 $p$ か らの空間的ボケ $S$ の影響を受けることになる．逆投影輝度 は焦点面でのリフォーカス画像の輝度值であるので，ボケ 幅 $b^{\prime}$ は，逆投影輝度の焦点面での空間的ボケの幅 $b$ と等価 である。したがって, 点 $q$ の輝度值と点 $q^{\prime}$ の輝度值は等価 となる。ここで，空間的ボケは図 8 に示すように，注目す る点の位置 $\left(x_{i}, y_{i}, z_{i}\right)$ によって異なる形状を有すると考元 られる。位置 $\left(x_{i}, y_{i}, z_{i}\right)$ における空間的ボケを考えるため, 媒介変数 $\xi_{r}, \xi_{s}, \xi_{t}$ を

$$
\begin{aligned}
\xi_{r} & =\frac{x_{\text {len }}}{z_{\text {len }}}-\frac{x_{i}}{z_{i}} \\
\xi_{s} & =\frac{y_{\text {len }}}{z_{\text {len }}}-\frac{y_{i}}{z_{i}} \\
\xi_{t} & =\frac{1}{z_{i}}-\frac{1}{z_{\text {len }}}
\end{aligned}
$$

と定義する。これにより, 空間的ボケは媒介变数 $\xi_{r}, \xi_{s}, \xi_{t}$ を用いて一様に表現することが可能となり，ライトフィー ルドの空間的ボケを式 (16) に示す関数で表現できる。な 㧍，導出過程は附録に示す。

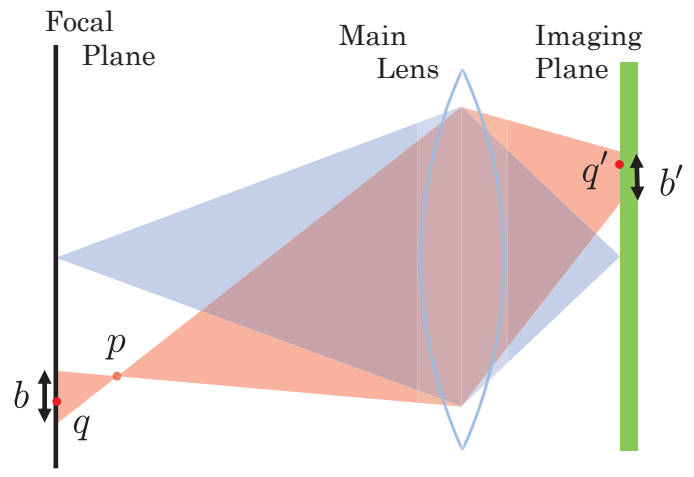

図 7 ボケ幅とレンズとの距離の関係

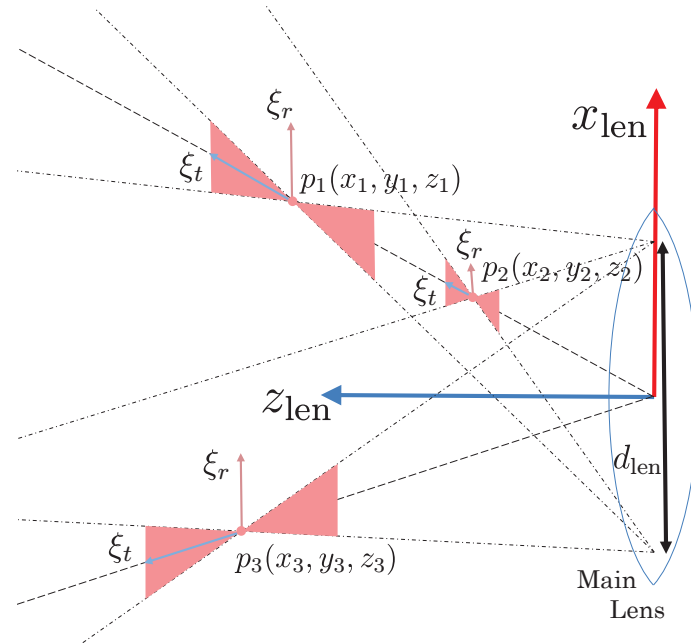

図 8 各位置におけるボケ

$$
S\left(\xi_{r}, \xi_{s}, \xi_{t}\right)=\left\{\begin{array}{cc}
\frac{1}{4 \xi_{t}^{2}} & \left(\left|2 \xi_{r} / d_{\text {len }}\right| \leqq\left|\xi_{t}\right|\right. \\
0 & \left.\left|2 \xi_{s} / d_{\text {len }}\right| \leqq\left|\xi_{t}\right|\right)(16)
\end{array}\right.
$$

（2）濃度分布の更新

式 (7) と式 (16) より逆投影されたライトフィールド $D_{\text {pro }}$ は，以下の式のように真の空間濃度分布 $D_{\text {true }}$ に空間的ボ ケ $S$ が畳み込まれたものであると見なすことができる。

$$
D_{\text {pro }}=D_{\text {true }} * S
$$

同様に，推定した空間濃度分布 $D_{\text {est }}$ に扔いても，以下の 式のように空間的ボケを考慮した空間濃度分布 $D_{\mathrm{blur}}$ を考 える。

$$
D_{\text {blur }}=D_{\text {est }} * S
$$

ここで， $D_{\mathrm{blur}}$ が $D_{\mathrm{pro}}$ と等しいとき, 提案手法により推定 した空間濃度分布 $D_{\text {est }}$ もまた真の空間濃度分布 $D_{\text {true }}$ と等 しくなる。したがって提案手法では，以下に示すように誤 差関数 $E$ を定義する。

$$
E=\sum_{j} \iiint\left\{D_{\text {pro }, j}(\boldsymbol{x})-D_{\text {blur }, j}(\boldsymbol{x})\right\}^{2} d x d y d z
$$


トフィールドの逆投影輝度であり， $D_{\mathrm{blur}, j}$ は，推定された

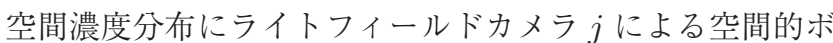
ケを重畳したものである。この誤差関数 $E$ が最小となる 時， $D_{\text {est }}$ は真の空間濃度分布 $D_{\text {true }}$ と同等であると考えら れる。したがって，Eが最小となる $D_{\text {est }}$ を繰り返し計算に より求めることで，最終的な空間濃度分布を推定する。本 論文では，空間濃度分布の更新に以下に示すような最急降 下法を用いる。

$$
D_{\mathrm{est}, n+1}(\boldsymbol{x})=D_{\mathrm{est}, n}(\boldsymbol{x})-k \frac{\partial E}{\partial D_{\mathrm{est}, n}(\boldsymbol{x})}
$$

ここで $k$ は各更新毎の更新量を決定する係数である. $D_{\text {est }, 0}(\boldsymbol{x})$ は， 4.2 節で決定した初期濃度分布 $D_{\text {init }}(\boldsymbol{x})$ で ある。この計算を $k \partial E / \partial D_{\mathrm{est}, n}(\boldsymbol{x})$ が閾值以下になるまで 繰り返す。

\section{5. 実 験}

本節では, 提案手法の有用性を示すため, 煙をライトフィー ルドカメラで撮影した画像をシミュレーションにより作成 し，その画像より空間濃度分布を提案手法により推定した 結果について述べる。さらに，実際にライトフイールドカ メラを用いて煙の空間濃度分布を推定した結果について述 ベる.

5.1 シミュレーション実験

煙をライトフィールドカメラで撮影した画像をシミュレー ションにより作成し, その画像より空間濃度分布を推定し, 空間濃度分布の推定精度およびボケ除去の有効性について 検証する。

（1）実験環境と計測対象

シミュレーションで想定した環境を図 9 に示す。煙は一 辺が $100 \mathrm{~mm}$ の立方体内に存在し, その立方体の中心から $100 \mathrm{~mm}$ 離れた位置に二台のライトフィールドカメラ同士 の向きが 90 度になるように配置した。 ライトフィールド カメラの台数は，実用的で簡便な推定システムを想定する ために二台とした。光源は, 二台のライトフィールドカメ ラとの光軸の角度が 45 度になる位置 (二台のライトフィー ルドカメラの間) で，煙を上方 45 度から照らす高さに設置 した。煙の濃度值の範囲は $0.0 \sim 1.0$ とし，一辺が $100 \mathrm{~mm}$ の立方体の空間を $100^{3}$ 個のボクセルで区切り, 各ボクセル の濃度を推定した。

ライトフィールドカメラによる撮影画像は，実際のライ トフィールドカメラにより得られる画像を考慮して, 縦横そ れぞれ 10 台の仮想カメラにより構成されるカメラアレイの 画像としてレンダリングした。また，実際のライトフィー ルドカメラの開口を想定し, 開口が $6 \mathrm{~mm}$ であるライト フィールドカメラにより得られる画像と等価な画像を得る ため,カメラ間距離を $0.67 \mathrm{~mm}$ とした。今回の実験では実 験結果から光源の指向性による影響を排除するため，いず れのライトフィールドカメラからも光源の光軸とカメラの

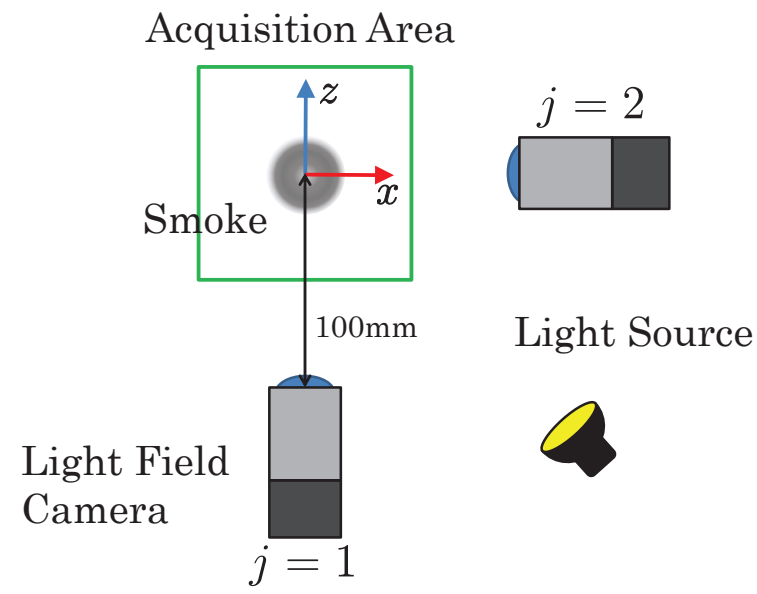

図 9 実験環境

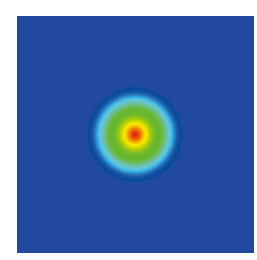

(a) $D_{\text {true }}(y=0)$
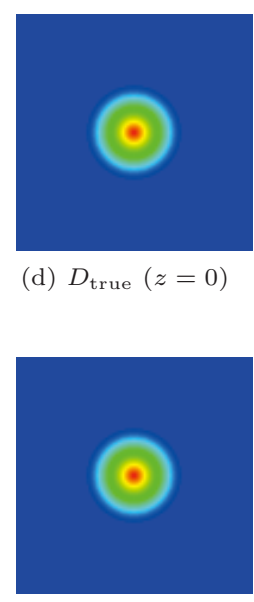

(g) $D_{\text {true }}(x=0)$ (d) $D_{\text {true }}(z=0)$

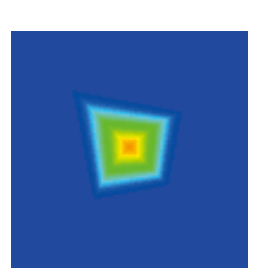

(b) $D_{\text {init }}(y=0)$

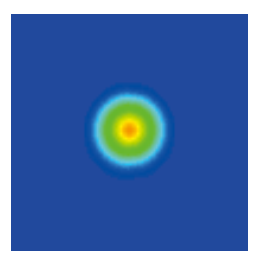

(e) $D_{\text {init }}(z=0)$

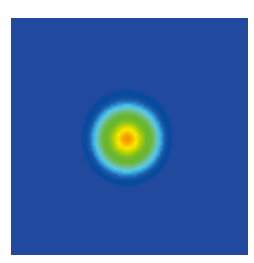

(h) $D_{\text {init }}(x=0)$

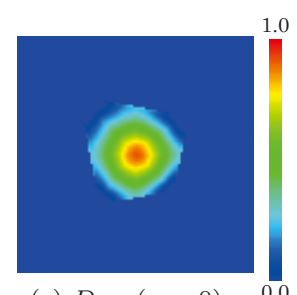

(c) $D_{\text {est }}(y=0)$

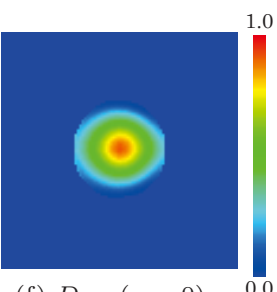

(f) $D_{\text {est }}(z=0)$

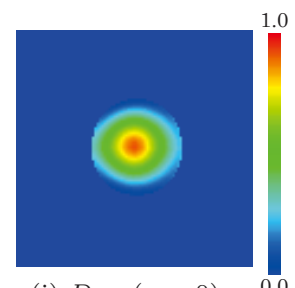

(i) $D_{\text {est }}(x=0)$
図 10 推定結果：球状

光軸の成す角が等しくなるように配置した．また，本研究 では濃度の希薄な煙を対象しているため，光源からの光は 減衰せずに各ボクセルに到達し，濃度に応じて等方散乱す る.したがって，シミュレーション画像はレイトレースに 基づいて，以下の式より生成した。

$$
I(X, Y)=\sum_{C_{X Y}} D_{\text {true }}
$$

$\sum_{C_{X Y}}$ は $I(X, Y)$ の光線方向にボクセルの濃度を加算す ることを意味する。

提案手法の有効性を調べるため，まず図 10 (a) (d) (g) に示すような境界が曖昧で対称性の高い煙の空間濃度分布 （球状）を推定する実験を行った。図 10 (a) (d) (g) はそれ ぞれ，対象とした煙の真の空間濃度分布 $D_{\text {true }}$ の断面の濃 


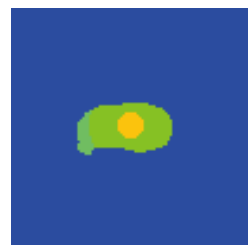

(a) $D_{\text {true }}(y=0)$

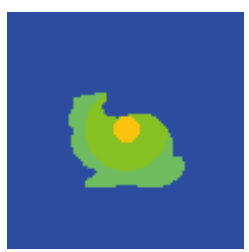

(d) $D_{\text {true }}(z=0)$

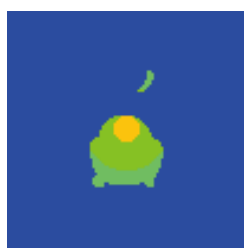

(g) $D_{\text {true }}(x=0)$

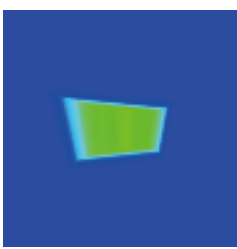

(b) $D_{\text {init }}(y=0)$

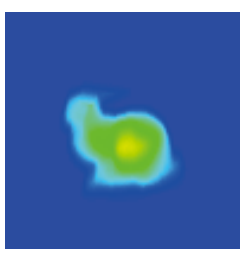

(e) $D_{\text {init }}(z=0)$

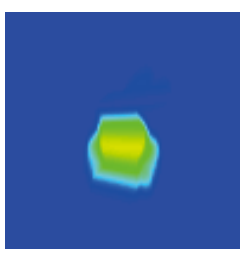

(h) $D_{\text {init }}(x=0)$

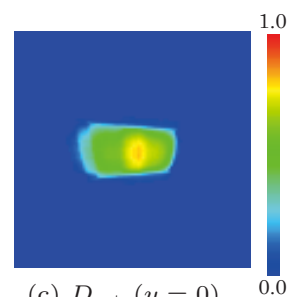

(c) $D_{\text {est }}(y=0)$

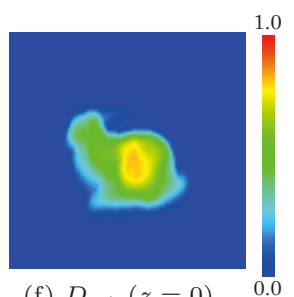

(f) $D_{\text {est }}(z=0)$

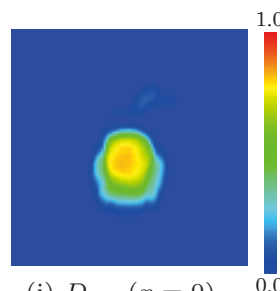

(i) $D_{\text {est }}(x=0)$
図 11 推定結果：Bunny 状

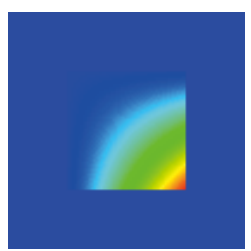

(a) $D_{\text {true }}(y=0)$

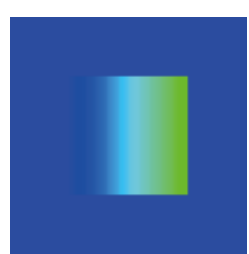

(d) $D_{\text {true }}(z=0)$

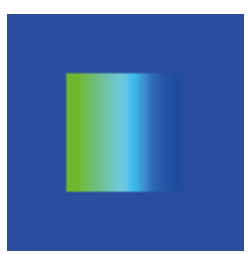

(g) $D_{\text {true }}(x=0)$

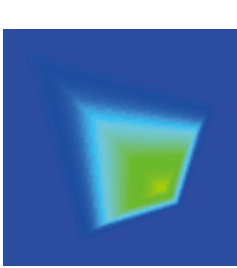

(b) $D_{\text {init }}(y=0)$

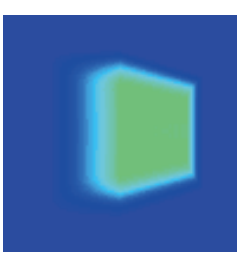

(e) $D_{\text {init }}(z=0)$

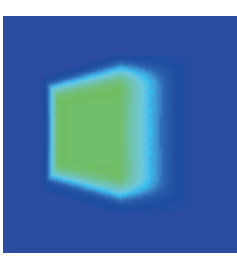

(h) $D_{\text {init }}(x=0)$

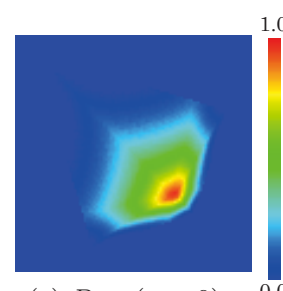

(c) $D_{\text {est }}(y=0)$

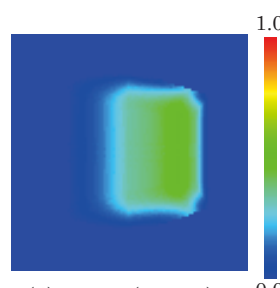

(f) $D_{\text {est }}(z=0)$

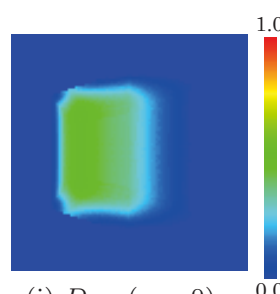

(i) $D_{\text {est }}(x=0)$
図 12 推定結果：立方体状

度であり，(a) は上から見た $y=0$ の断面，(d) は $j=1$ のライトフィールドカメラから見た $z=0$ の断面, $(\mathrm{g})$ は $j=2$ のライトフィールドカメラから見た $x=0$ の断面の 濃度である, 対象とする煙の濃度は, 煙の存在する領域の 中心からの距離に応じて線形に減少するものとし, その值

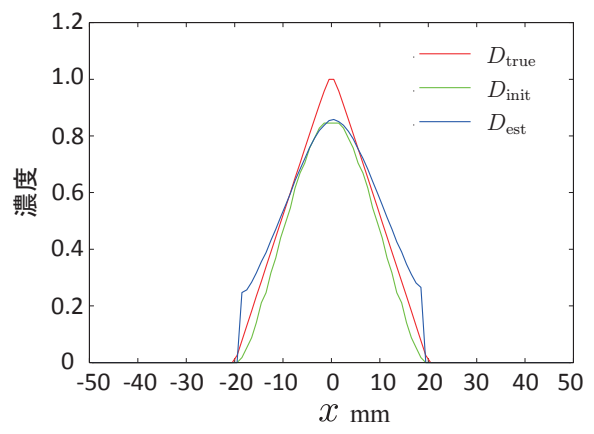

図 $13 y=z=0$ における推定結果: 球状

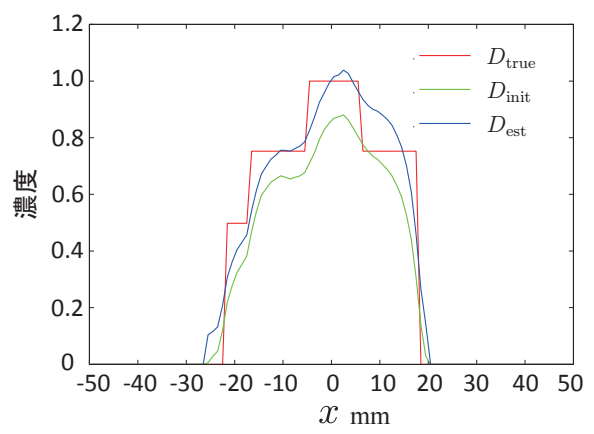

図 $14 y=z=0$ に扮ける推定結果：Bunny 状

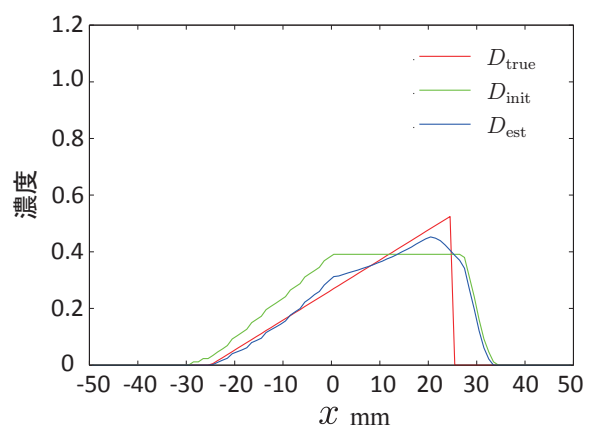

図 $15 y=z=0$ における推定結果：立方体状

は中心で 1.0 とし距離 $20 \mathrm{~mm}$ で 0.0 となるようにした。

次に, 図 11 (a) (d) (g) に示すような外形が複雑な煙 の空間濃度分布（Bunny 状）を推定する実験を行った。図 11 (a) (d) (g) はそれぞれ，対象とした煙の真の空間濃度 分布 $D_{\text {true }}$ の断面の濃度值である。対象とする煙は，外形 がStanford Bunny 状であり，濃度が中心からの距離によ りステップ状に変化するものとした。

さらに，図 12 (a) (d) (g) に示すように，境界が曖昧な 領域とはっきりした領域を持つ立方体状の煙の空間濃度分 布（立方体状）の推定実験を行った。煙の濃度は， $x=25$ $\mathrm{mm}, z=-25 \mathrm{~mm}$ で 1.0 となり, $x z$ 平面上の距離に応じ て線形に減衰し, 距離 $50 \mathrm{~mm}$ で 0.0 となるようにした。

これらの推定対象に対して濃度分布の一致度を定量的に 評価するため，分布一致度として以下の式を定義した。 


$$
\begin{aligned}
Q_{\text {sub }} & \left(\beta_{1}, \beta_{2}\right)= \\
& \sqrt[3]{\frac{N\left(A_{\text {sub }}\left(\beta_{1}, \beta_{2}\right) \cap A_{\text {true }}\left(\beta_{1}, \beta_{2}\right)\right)}{N\left(A_{\text {sub }}\left(\beta_{1}, \beta_{2}\right) \cup A_{\text {true }}\left(\beta_{1}, \beta_{2}\right)\right)}}
\end{aligned}
$$

sub は初期（init）または推定結果（est）を表す添字であ る. $A_{\mathrm{sub}}\left(\beta_{1}, \beta_{2}\right)$ は, $\beta_{1}<D_{\mathrm{sub}}(\boldsymbol{x}) \leqq \beta_{2}$ となる $D_{\mathrm{sub}}$ の 内のボクセルの集合であり， $N(A)$ は集合 $A$ のボクセルの 数を表す．分布一致度の結果を図 16〜18 に示す。分布一 致度は, 真の濃度分布 $D_{\text {true }}$ の值を三等分するように, $\beta_{1}$, $\beta_{2}$ を設定した。この指標により初期濃度分布の分布一致度 $Q_{\text {init }}$ と推定結果の分布一致度 $Q_{\text {est }}$ を算出した。

また，推定結果の各位置での濃度值を評価する指標とし て，真值との誤差值を以下のように定義した。

$$
\varepsilon_{\text {sub }}=\frac{\sum_{x} \sum_{y} \sum_{z}\left|D_{\text {sub }}-D_{\text {true }}\right|}{N_{\text {true }}}
$$

sub は初期（init）または推定結果（est）を表す添字であ る. $N_{\text {true }}$ は， $D_{\text {true }}$ の濃度が 0 でないボクセルの数であ る.この指標により初期濃度分布の誤差值 $\varepsilon_{\text {init }}$ と推定結果 の誤差值 $\varepsilon_{\text {est }}$ を算出した。この結果を表 1 に記す。

また，以下の式により相関を求めた結果を表 2 に記す.

$$
\begin{aligned}
& C_{\text {sub }}= \\
& \frac{\sum_{x} \sum_{y} \sum_{z}\left(D_{\text {sub }}-\bar{D}_{\text {sub }}\right)\left(D_{\text {true }}-\bar{D}_{\text {true }}\right)}{\sqrt{\Phi_{\text {sub }} \Phi_{\text {true }}}} \\
& \Phi_{\text {sub }}=\sum_{x} \sum_{y} \sum_{z}\left(D_{\text {sub }}-\bar{D}_{\text {sub }}\right)^{2} \\
& \Phi_{\text {true }}=\sum_{x} \sum_{y} \sum_{z}\left(D_{\text {true }}-\bar{D}_{\text {true }}\right)^{2}
\end{aligned}
$$

$\bar{D}_{\text {sub }}, \bar{D}_{\text {true }}$ はそれぞれ， $D_{\text {sub }} ， D_{\text {true }}$ の平均值を表す.

(2) 結 果

図 10 (b) (e) (h) に推定した初期濃度分布 $D_{\text {init }}$ を示 す。この初期濃度分布 $D_{\text {init }}$ から空間的ボケを除去した結 果 $D_{\text {est }}$ を図 10 (c) (f) (i) に示す。提案手法による濃度 の值は， $D_{\text {init }}, D_{\text {est }}$ 共に相対的な值となる。したがって， 濃度分布の類似性を評価するため， $D_{\text {init }}$ と $D_{\mathrm{est}}$ にそれぞ れの $\varepsilon$ が最小となる係数を掛けてスケーリングを行った. また， $y=z=0$ における推定結果を図 13 に示す. 図 10 (e) および (h) は概ね外形と濃度分布が正しく推定できて

表 1

\begin{tabular}{ccc} 
真の濃度分布と推定值との平均誤差 \\
\hline & $C_{\text {init }}$ & $C_{\text {est }}$ \\
\hline 球状 & 0.075 & 0.057 \\
Bunny 状 & 0.354 & 0.298 \\
立方体状 & 0.161 & 0.103 \\
\hline
\end{tabular}

表 2 真の濃度分布と推定值との濃度分布の相関

\begin{tabular}{crr}
\hline & $\varepsilon_{\text {init }}$ & $\varepsilon_{\text {est }}$ \\
\hline 球状 & 0.965 & 0.982 \\
Bunny 状 & 0.873 & 0.911 \\
立方体状 & 0.840 & 0.897 \\
\hline
\end{tabular}

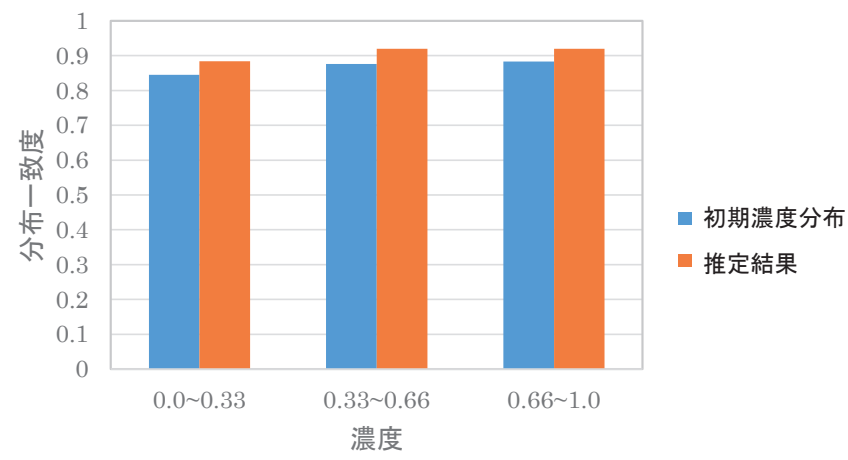

図 16 球状の分布一致度

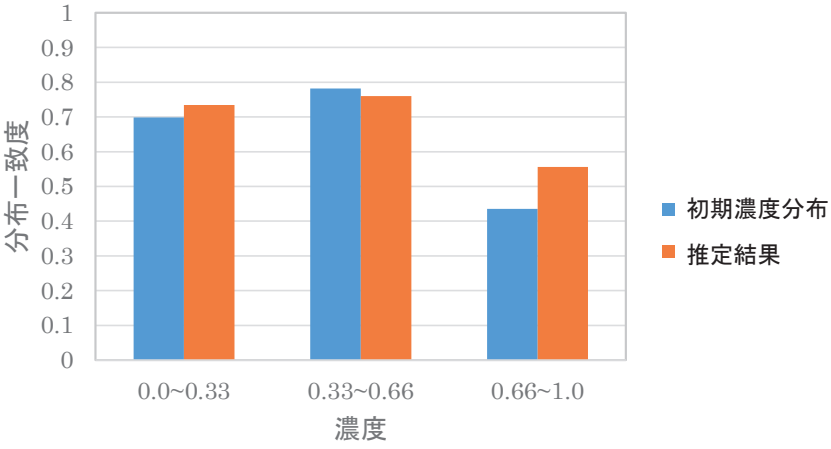

図 17 Bunny 状の分布一致度

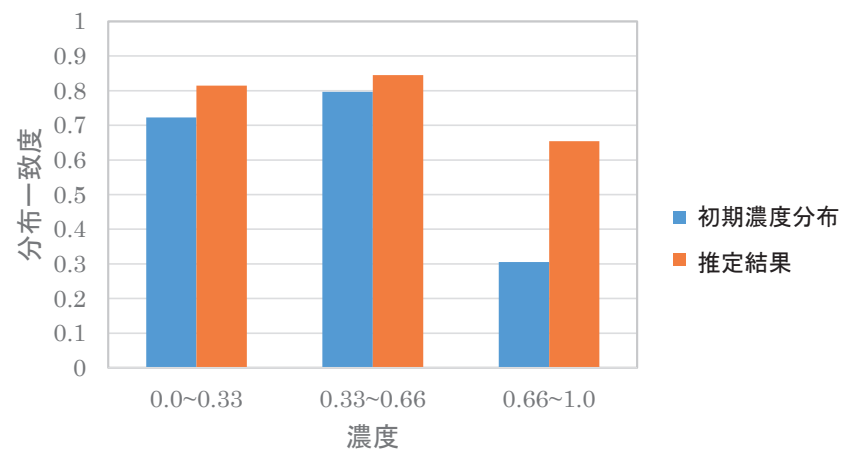

図 18 立方体状の分布一致度

いることがわかる。しかし，(b) に関しては外形が大きく 異なり，空間的ボケ除去前の初期濃度分布では不充分であ ることがわかる。一方，図 10 (c) を見ると，初期濃度分布 から空間的ボケが除去されることで推定した濃度分布が真 值に近づたことが確認できる。しかし，図 10 (f) (i)の $z=0, x=0$ の断面においては, 濃度が左右に広がって いることが確認できる。図 16 を見ると，空間的ボケの除 去によりすべての分布一致度が増加したことが確認できる. これは図 $10(\mathrm{~b})$ の $y=0$ の断面に見える四角状の分布が， 空間的ボケの除去により円状に近づいためであると考え られる。この結果から，境界が曖昧な煙の空間濃度分布を 推定できることが確認できた。

図 11 (b)（e)（h）に推定した初期濃度分布 $D_{\text {init }}$ を示 す。この初期濃度分布 $D_{\text {init }}$ から空間的ボケを除去した結 果 $D_{\mathrm{est}}$ を図 11 (c) (f) (i) に示す。また， $y=z=0$ に おける推定結果を図 14 に示す。図 11 では，煙が存在して 
いる範囲を推定できていることが確認できる．空間的ボケ の除去により推定した濃度が真值に近づいたことが確認で きる。図 17 を見ると，空間的ボケ除去により濃度（0.0〜 0.33，0.66〜 1.0）の分布一致度は増加したが，濃度（0.33〜 0.66)においては減少した。これは図 11 (b)の $y=0$ の断 面に見える四角状の分布が，空間的ボケの除去により真の 濃度分布に近づくため，すべての分布一致度が増加する一 方で, 濃度 (0.33〜0.66) のボクセルの一部が濃度 $(0.66$ 1.0）になったため濃度（0.33～0.66）では減少したと考え られる。この結果から, 煙の外形が複雑であっても推定す ることができることが確認できた。

図 12 (b) (e) (h) に推定した初期濃度分布 $D_{\text {init }}$ を示 す.この初期濃度分布 $D_{\text {init }}$ から空間的ボケを除去した結果 $D_{\mathrm{est}}$ を図 12 (c) (f) (i) に示す。また, 図 15 に, $y=z=0$ における推定結果を示す。眓 12 でも同様に, 空間的ボケの 除去により推定した濃度が真值に近づいたことが確認でき る。また，煙が存在している範囲は，ボケ除去により真值 に近づいていることがわかる。空間的ボケモデルはカメラ の透視投影の影響を考慮しており，この結果はボケ除去に より初期濃度分布の透視投影の影響を補正することができ たことを示している。一方，煙が存在している境界でボケ たような推定結果が確認された。これは，提案している空 間的ボケ除去手法により，空間的ボケが完全には除去でき ていないことが原因であると考えられる。これは，解の不 定性によるものであるためライトフィールドカメラの台数 を増やすことで改善できると考えられる。また，図 18 を見 ると, 空間的ボケの除去によりすべての分布一致度が増加 したことが確認できる．特に濃度（0.66～1.0）の増加が大 きいが，これは濃度（0.66１.0）のボクセルの数が少ない ため変動が大きくなったと考えられる。この結果から，境 界が曖昧な領域とはっきりした領域を持つ場合でも推定で きることが確認できた。

また表 1 に示すように，すべての対象においてボケ除去 により誤差值が減少したことが確認できる，表 2 に示すよ うに，相関についてもすべての対象でボケ除去により相関 が大きくなった。これは初期濃度分布を与える際の解の不 定性が，空間的ボケの除去によって緩和されたためである。 この結果からも空間濃度分布を正しく推定するために，提 案したボケ除去の手法が有効であることが確認できる。ま た, Bunny 状の対象の誤差值が他の対象に比べて高くなっ た。これは，光線方向の濃度の積分值が同じでも分布は異 なる場合がある，という解の不定性により，光線の奥行方 向に広く分布する場合と, 局所的に濃度が高い分布の場合 との区別がつかないこと, 対象が非対称性の場合は必ずし も最小值を割り当てるのが良いわけではないことが原因で あると考えられる。これらの結果から，提案手法は濃度分 布が連続的に変化している煙の濃度分布を推定することに 適しており，濃度が急激に変化する濃度分布に対しては精 度が低下することがわかった。

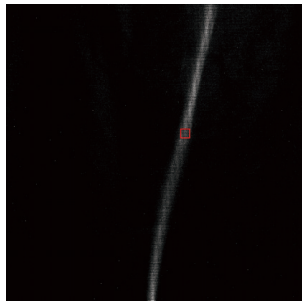

(a) 取得画像

図 19 ライトフィールドカメラによる取得画像の例

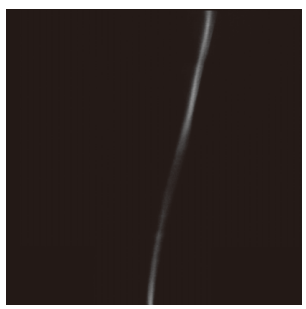

(a) $j=1$

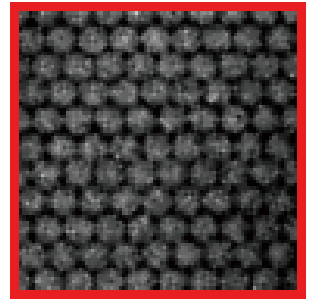

(b) 拡大画像

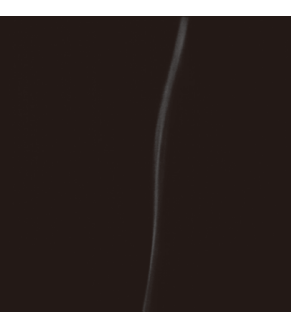

(b) $j=2$
図 20 リフォーカス画像

\section{2 実測実験}

実際のライトフィールドカメラを用いて，煙の空間濃度 分布が推定できることを示すため，実測実験を行った。

（1）実験環境

図 9 に示すように，シミュレーション実験と同じ配置で 実測実験を行った。一辺が $100 \mathrm{~mm}$ の立方体の空間を煙の 推定範囲とし，二台のライトフィールドカメラ (Lytro 社 製 Lytro）は，推定範囲の中心から $100 \mathrm{~mm}$ 離れた位置に ライトフィールドカメラ同士の光軸の向きが 90 度になるよ うに設置した。煙は, 推定範囲の下方に線香を設置し, 線 香により発生させた煙を用いた。また，光源には白色光源 を用いて，煙から $1000 \mathrm{~mm}$ 離れた位置にライトフィール ドカメラと光源の角度が 45 度になる位置で, 煙を上方 45 度から照らす高さに設置した。図 19 に示すようなライト フィールドカメラにより取得された画像から図 20 に示す ようなリフォーカス画像を生成した。各ライトフィールド カメラにより取得したリフォーカス画像の一部を図 20 に 示す。また，煙の推定範囲を $100^{3}$ 個のボクセルで区切り, 各ボクセルの濃度值を推定した。また，推定した空間濃度 分布 $D_{\mathrm{est}}$ をレンダリングした画像が実際に正しいかどうか 検証するため，推定に使用していない方向から通常のカメ ラにより煙を撮影した画像と，同じ方向からレンダリング した画像を比較した。通常のカメラ（Nikon 社製 D5000） は，二台のライトフィールドカメラの間（ライトフィール ドカメラの光軸との角度が 45 度）になる位置に設置した. また，空間濃度分布の推定がレンダリングに重要であるこ

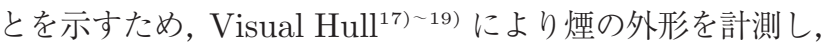
内部の濃度を一定としてレンダリングした結果と比較した。

(2) 結 果

図 21 (a) (d) に, 各ライトフィールドカメラにより取得 したリフォーカス画像の一部を示す。二台のライトフィー ルドカメラの間から通常のカメラにより撮影した画像を図 


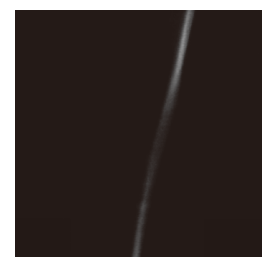

(a) 撮影画像 $(j=1)$

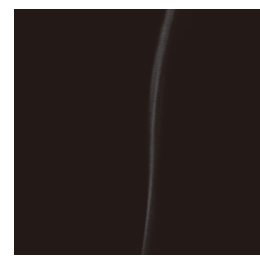

(d) 撮影画像 $(j=2)$

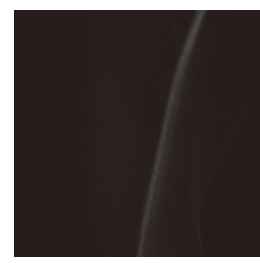
(通常のカメラ) (g) 撮影画像

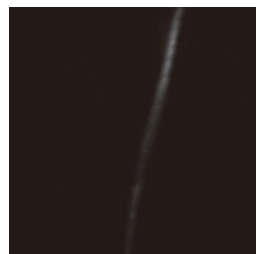

(b) 提案手法 $(j=1)$

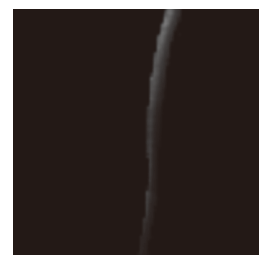

(e) 提案手法 $(j=2)$

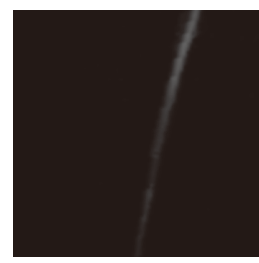

(h) 提案手法 $\left(45^{\circ}\right)$

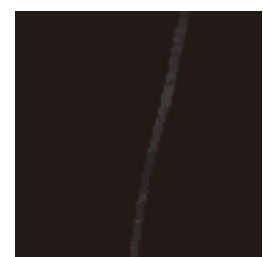

(c) Visual Hull $(j=1)$

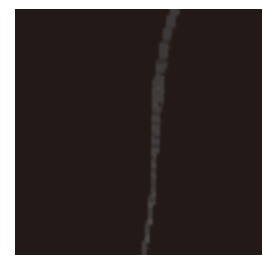

(f) Visual Hull $(j=2)$

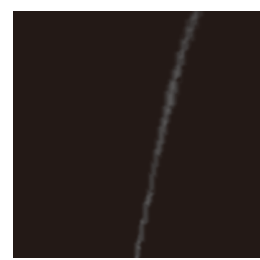

(i) Visual Hull $\left(45^{\circ}\right)$
図 21 レンダリング結果: (a) (d) リフォーカス画像, (g) 通常 のカメラによる撮影画像, (b) (e) (h) 推定結果 $D_{\text {est }}$ の レンダリング画像, (c) (f) (i) 濃度を一定としたVisual Hull のレンダリング結果

21 (g) に示す。図 21 (b) (e) (h) はそれぞれ，推定した 空間濃度分布 $D_{\mathrm{est}}$, ライトフィールドカメラ $j=1, j=2$ および通常のカメラの位置から見た場合の画像をレンダリ ングした結果である。また，比較のため，図 21 (c) (f) (i) に Visual Hull17) 19) の濃度を一定としてレンダリングした 結果を示す.

図 21 (a) (b) (d) (e) を見ると, 推定した空間濃度分布 $D_{\text {est }}$ のレンダリング結果は, ライトフィールドカメラの取 得画像と類似していることが確認できる。ささらに, 図 $21(\mathrm{~g})$ (h) を見ると, 推定した空間濃度分布 $D_{\text {est }}$ が, 通常のカメ ラにより得られた画像と類似していることが確認できる. このことから，推定結果を用いて，空間濃度分布の推定に 使用していないカメラの方向から見た場合の煙の画像をレ ンダリングできることが確認できる。一方，図 21 (c) (f) (i)に示す Visual Hull のレンダリング結果は, 煙の存在す る範囲は反映されているが，濃度分布に関しては不充分で あることがわかる．また，Visual Hull の結果は境界で輝 度值が不連続に変化していることがわかる。一方提案手法 では，実際の煙のように煙の境界が曖昧になっていること が確認できる。これらの結果より, 提案手法が濃度の低い 煙の空間濃度分布の推定に適していることが確認できた。

\section{3 考 察}

提案手法では, 散乱の指向性 $P(\theta)$ を無視するため, 光源 の光線と各ライトフィールドカメラの光軸の角度 $\theta$ が同じ
になるように配置している，そのため，ライトフィールド カメラの設置位置に制限がある。この制限については，今 後モデルに散乱の指向性を導入することで緩和できると考 えられる。また，ライトフィールドカメラは，カメラに近 い位置ほど多くの濃度に関する情報を取得する特性を持っ ている。したがって，ライトフィールドカメラの遠方では， 推定精度が低下する問題がある。また，提案手法では4)5) と 同様に，濃度の低い煙を対象とすることで，多重散乱や減 衰を無視してモデル化を行っている。多重散乱は全体の散 乱光を強くし，減衰はカメラ遠方からの散乱光ほど弱くす る。したがって, 現在の提案手法で濃度の高い煙の空間濃 度分布を推定した場合には，逆に，多重散乱は全体の濃度 を低く, 減衰はカメラ遠方の濃度ほど高く推定させる影響 を持つ。これらの影響を除去するために，濃度の高い煙に 対してはこれらの現象をモデルに追加することが必要であ ると考えられる。また，提案手法では空間濃度分布の更新 に最急降下法を用いているため, 解が局所解に収束してい る可能性がある。したがって，より最適解に収束する可能 性の高い遺伝的アルゴリズムや焼きなまし法を用いること で，推定精度が向上すると考えられる。また，煙の空間濃 度分布を時間的に推定することで煙の流れを推定すること ができると考えられる。

\section{6. むすび}

本論文では，ライトフィールドカメラを用いることで一 度の撮影で，煙の空間濃度分布を推定する手法を提案した。 提案手法では, 取得したライトフィールドと等しいライト フィールドを発生させる煙の空間濃度分布を推定すること でより正しい空間濃度分布が得られる。まず，二台のライト フィールドカメラによって煙を撮影した画像をシミュレー ションにより作成し，提案手法により煙の空間濃度分布を 推定する実験を行ったところ，空間的ボケ除去により濃度 分布の一致度が増加することが確認できた。この結果，空 間的ボケ除去の有効性が示唆された。さらに, 実際にライ トフィールドカメラを用いて，煙の計測を行い，提案手法 により実際の煙の空間濃度分布を推定できることを示した。 提案手法では，特定の時刻に扔ける煙の空間濃度分布を推 定することが可能である。したがって，各時間に扔ける空 間濃度分布を推定することで, 動的に変動する煙の濃度分 布を推定でき，煙の流れの推定に応用できると考えられる．

〈付録〉

\section{A. 空間的ボケの媒介変数による表現}

まずは付・図 1 に示すように，点 $\mathrm{A}\left(0,0, L_{p}\right)$ を中心とし て広がる空間的ボケを考える。このとき，ボケ幅bは式(付 •1)のように表せる.

$$
b=\frac{L_{q}}{L_{p}} d_{\text {len }}
$$

つぎに, 位置 $\left(x_{i}, y_{i}, z_{i}\right)$ における空間的ボケを考えるため, 


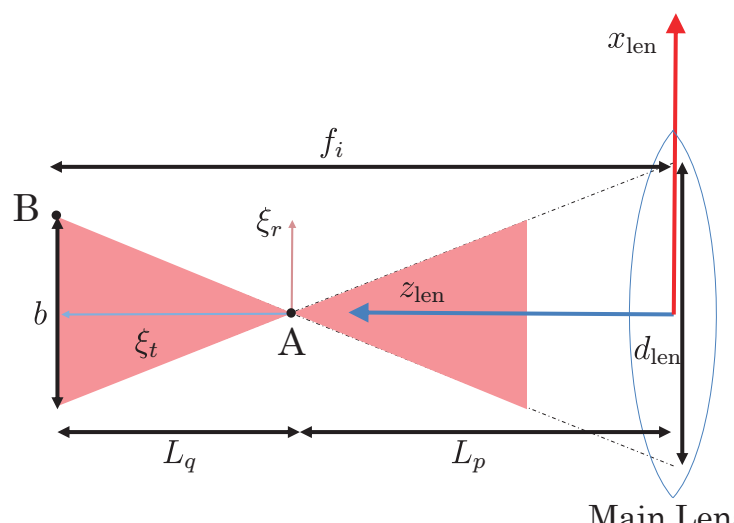

付・図 1 空間的ボケのモデル化

媒介变数 $\xi_{r}, \xi_{s}, \xi_{t}$ を

$$
\begin{aligned}
\xi_{r} & =\frac{x_{\text {len }}}{z_{\text {len }}}-\frac{x_{i}}{z_{i}} \\
\xi_{s} & =\frac{y_{\text {len }}}{z_{\text {len }}}-\frac{y_{i}}{z_{i}} \\
\xi_{t} & =\frac{1}{z_{i}}-\frac{1}{z_{\text {len }}}
\end{aligned}
$$

と定義する。ここで, $\xi_{r}, \xi_{t}$ について着目すると, 点 $\mathrm{A}\left(0,0, L_{p}\right)$ における空間的ボケは以下のようになる.

$$
\begin{aligned}
\xi_{r} & =\frac{x_{\text {len }}}{z_{\text {len }}}-\frac{0}{L_{p}}=\frac{x_{\text {len }}}{z_{\text {len }}} \\
\xi_{t} & =\frac{1}{L_{p}}-\frac{1}{z_{\text {len }}}
\end{aligned}
$$

このとき, ボケの境界である点 $\mathrm{B}\left(b / 2, f_{i}\right)$ を媒介変数で表 現すると以下のようになる。

$$
\begin{aligned}
\xi_{r} & =\frac{b / 2}{f_{i}} \\
\xi_{t} & =\frac{1}{L_{p}}-\frac{1}{f_{i}}=\frac{f_{i}-L_{p}}{f_{i} L_{p}}
\end{aligned}
$$

式（付·7）に式（付·1）を代入し, $L_{q}=f_{i}-L_{p}$ の関係か ら，ボケの境界の $\xi_{r}$ と $\xi_{t}$ の関係を得る。

$$
\xi_{r}=\frac{L_{q} d_{\text {len }}}{2 f_{i} L_{p}}=\frac{\left(f_{i}-L_{p}\right) d_{\text {len }}}{2 f_{i} L_{p}}=\frac{d_{\text {len }}}{2} \xi_{t}
$$

$\xi_{s}$ についても同様に

$$
\xi_{s}=\frac{d_{\text {len }}}{2} \xi_{t}
$$

となる。したがって, 空間的ボケは以下のように表現できる.

$$
S\left(\xi_{r}, \xi_{s}, \xi_{t}\right)=\left\{\begin{array}{cl}
\frac{1}{4 \xi_{t}^{2}} & \left(\left|2 \xi_{r} / d_{\text {len }}\right| \leqq\left|\xi_{t}\right|,\right. \\
0 & \left(2 \xi_{s} / d_{\text {len }}|\leqq| \xi_{t} \mid\right)(\text { 付 } \cdot 11) \\
& \text { (otherwise) }
\end{array}\right.
$$

[文献]

1) W. Matusik, H. Pfister, A. Ngan, P. Beardsley, R. Ziegler, and L. McMillan. Image-based 3d photography using opacity hulls. ACM Trans. Graphics, 21, 3, pp. 427-437 (2002)

2) F. Bernardini, I. M. Martin, and H. Rushmeier. High-quality texture reconstruction from multiple scans. IEEE Trans. Visualization and Computer Graphics, 7, 4, pp. 318-332 (2001)

3) C. Inoshita, Y. Mukaigawa, Y. Matsushita, and Y. Yagi. Shape from single scattering for translucent objects. In Proc. Computer Vision-ECCV 2012, pp. 371-384. Springer, (2012)

4) T. Hawkins, P. Einarsson, and P. Debevec. Acquisition of timevarying participating media. ACM Trans. Graphics, 24, 3, pp. 812-815 (2005)

5) C. Fuchs, T. Chen, M. Goesele, H. Theisel, and H. P. Seidel. Density estimation for dynamic volumes. Computers \& Graphics, 31, 2, pp. 205-211 (2007)

6) E. H. Adelson and J. Y. A. Wang. Single lens stereo with a plenoptic camera. IEEE Trans. Pattern Analysis and Machine Intelligence, 14, 2, pp. 99-106 (1992)

7) B. Wilburn, N. Joshi, V. Vaish, Eino-Ville Talvala, E. Antunez, A. Barth, A. Adams, M. Horowitz, and M. Levoy. High performance imaging using large camera arrays. ACM Trans. Graphics, 24, 3, pp. 765-776 (2005)

8) R. Ng, M. Levoy, M. Brdif, G. Duval, M. Horowitz, and P. Hanrahan. Light field photography with a hand-held plenoptic camera. Stanford University Computer Science Tech Report CSTR (2005)

9) K. Maeno, H. Nagahara, A. Shimada, and R. Taniguchi. Light field distortion feature for transparent object recognition. In Proc. IEEE Conf. Computer Vision and Pattern Recognition, pp. 2786-2793 (2013)

10) J. Yu, J. Ye, and J. Yu. Reconstructing gas flows using light-path approximation. In Proc. IEEE Conf. Computer Vision and Pattern Recognition, pp. 2507-2514 (2013)

11) K. Koshikawa. A polarimetric approach to shape understanding of glossy objects. In Proc. International Joint Conf. Artificial Intelligence, pp. 493-495 (1979)

12) M. Saito, Y. Sato, K. Ikeuchi, and H. Kashiwagi. Measurement of surface orientations of transparent objects by use of polarization in highlight. JOSA A, 16, 9, pp. 2286-2293 (1999)

13）宮崎大輔, 池内克史. 偏光と放物的曲線の解析による透明物体の表面形状 計測. 情報処理学会研究報告. CVIM, [コンピュータビジョンとイメー ジメディア], 44,pp. 86-93 (2003)

14) M. B. Hullin, M. Fuchs, I. Ihrke, H. P. Seidel, and H. Lensch. Fluorescent immersion range scanning. ACM Trans. Graphics, 27, 3 (2008)

15) K. Zhou, Z. Ren, S. Lin, H. Bao, B. Guo, and H. Y. Shum. Realtime smoke rendering using compensated ray marching. ACM Trans. Graphics, 27, 3, p. 36 (2008)

16) J. Gu, S. K. Nayar, E. Grinspun, P. N. Belhumeur, and R. Ramamoorthi. Compressive structured light for recovering inhomogeneous participating media. IEEE Trans. Pattern Analysis and Machine Intelligence, 35, 3, pp. 1-1 (2013)

17) B. G. Baumgart. Geometric modeling for computer vision. $P h D$ dissertation, aIM-249, STAN-CS-74-463, Computer Science Dept.,Stanford Univ. (1974)

18) C. H. Chien and J. K. Aggarwal. Volume/surface octress for the representation of three-dimensional objects. Computer Vision, Graphics, and Image Processing, 36, 1, pp. 100-113 (1986)

19) R. Szeliski. Rapid octree construction from image sequences. Computer Vision, Graphics, and Image Processing, 58, 1, pp. 23-32 (1993)
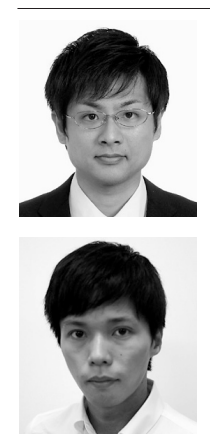

井手口゙裕太 2014 年大阪大学大学院基礎工学研究 科博士前期課程修了。同年同研究科博士後期課程進学, 現在に至る。三次元計測に関する研究に従事. システム 制御情報学会に所属.

浦西要方樹 2008 年奈良先端科学技術大学院大学 情報科学研究科博士後期課程修了. 博士 (工学). 同年日 本学術振興会特別研究員 PD. 2009 年奈良先端科学技術 大学院大学情報科学研究科助教. 2012 年大阪大学大学 院基礎工学研究科助教. 2014 年京都大学医学部附属病 院助教. 2016 年大阪大学サイバーメディアセンター准 教授，現在に至る。 2011 年フインランド・オウル大学客 員研究教授. 三次元形状計測，拡張現実感，ヒューマン コンピュータインタラクションに関する研究に従事. 電 子情報通信学会, システム制御情報学会, 日本バーチャ ルリアリティ学会, 日本生体医工学会, IEEE 等に所属. 


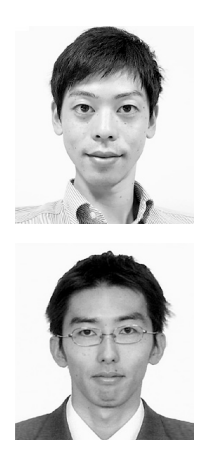

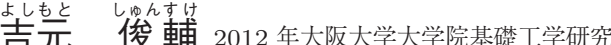
科博士後期課程修了. 博士 (工学)。同年同研究科助教, 現 在に至る. 力触覚, 生体計測に関する研究に従事. IEEE, 日本生体医工学会, 日本バーチャルリアリテイ学会, 電 子情報通信学会等に所属。

星苗 嘉ひ宏 2005 年京都大学大学院情報学研究科 博士後期課程修了. 博士 (情報学). 同年京都大学大学院 医学研究科特任助手. 2006 年大阪大学大学院基礎工学研 究科助教. 2013 年大阪大学サイバーメディアセンター 准教授. 2016 年大阪大学大学院基礎工学研究科准教授, 現在に至る。医用 VR，触覚情報処理，教育訓練システ ムに関する研究に従事，ACM，IEEE，日本バーチャル リアリティ学会, 日本生体医工学会, 日本 VR 医学会等 に所属.

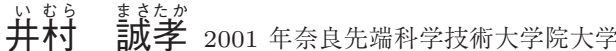
情報科学研究科博士後期課程修了. 博士 (工学). 同年同 研究科助手. 2007 年同研究科助教. 2009 年大阪大学大 学院基礎工学研究科准教授. 2015 年関西学院大学理工学 部教授, 現在に至る。人工現実感, ヒューマンコンピュー タインタラクションおよび生体医工学に関する研究に従 事. IEEE，情報処理学会，日本生体医工学会等に所属. 大扎城热声 1990 年大阪大学大学院基礎工学研究 科博士後期課程修了. 工学博士。同年住友金属工業 (株) 入社. 1993 年奈良先端科学技術大学院大学情報科学研究 科助手. 1994 年同大学先端科学技術研究調査センター助 教授. 2003 年大阪大学大学院基礎工学研究科教授, 現在 に至る。医用画像処理，生体信号処理に関する研究に従 事. 日本生体医工学会, システム制御情報学会等に所属. 